\section{En gripende bok om hvordan det er å være autist}

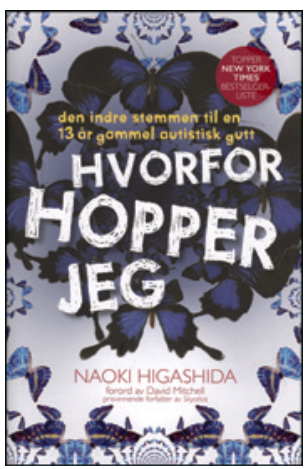

Naoki Higashida

Hvorfor hopper jeg

Den indre stemmen til en 13 år gammel autistisk gutt. 236 s, ill. Oslo: Pantagruel Forlag, 2014. Pris NOK 299

ISBN 978-82-7900-663-3

Boken ble opprinnelig utgitt på japansk og er skrevet av en gutt med autisme. Forfatteren Naoki Higashida har siden boken første gang ble publisert i Japan i 2007, skrevet flere bøker og driver nå som ung voksen sin egen blogg om autisme.

I boken møter vi 13 år gamle Naoki som har lært seg å kommunisere ved hjelp av en alfabettabell med de grunnleggende 40 japanske hiragana-tegnene. Ved hjelp av tabellen, som ble laget av Naokis mor, begynner gutten å forklare omverdenen hvordan det føles å være autist, og hvilke utfordringer dette byr på. Leseren blir invitert til å se livet fra Naokis perspektiv. I 58 korte, lettleste kapitler beskriver forfatteren godt hvordan det er å være autist, ved å svare på typiske spørsmål. Boken avsluttes med en gripende parabel som er meget tankevekkende. Det var den kjente forfatteren David Mitchell som oppdaget boken og laget den første uoffisielle oversettelsen sammen med sin japanske kone. I første omgang var den bare tenkt for å hjelpe lærerne til ekteparets autistiske sønn, men boken ble så populær at man bestemte seg for å publisere den på engelsk. Siden har den gått verden rundt. Det har vært en del diskusjoner om den engelske oversettelsen tilsvarer originalen, siden boken flere ganger ble omredigert av ekteparet Mitchell før publisering. Man må allikevel ta i betraktning at det japanske språket har mange idiomer som ikke lar seg oversette direkte til andre språk, samt at måten å fortelle på er spesiell. Etter at boken ble publisert på engelsk i 2013, har den klatret på bestselgerlistene i mange land i løpet av kort tid. Nå finnes det også en norsk oversettelse av den engelske versjonen. Boken er enestående og anbefales på sterkeste til alle som av yrkesmessige eller personlige grunner er opptatt av autisme.

\section{Uta Bastian}

Spesialist i barne- og ungdomspsykiatri

Privatpraksis for barne- og ungdomspsykiatri og -psykoterapi

Sankt Wendel, Tyskland

\section{Hasjmisbrukende grønlender}

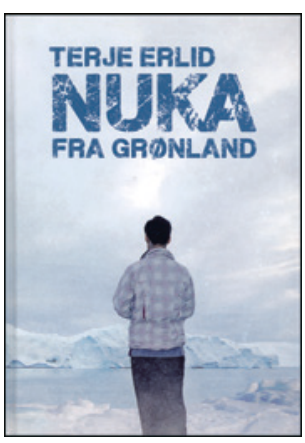

\section{Terje Erlid \\ Nuka fra Grønland}

102 s. Harstad: Medicteam, 2012

Pris NOK 349

ISBN-978-82-999051-3-8
I tre måneder arbeidet forfatteren som lege på Grønland. Der traff han en kvinnelig sosialpedagog som kontinuerlig brukte hasj, men som likevel med et nødskrik klarte å holde på jobben. Hun hadde flere barn og en større familie. Under oppveksten og som voksen opplevde hun incest, voldtekt, sult og fattigdom, og sto stadig i fare for å miste jobben. I lange perioder kunne hun ikke ta vare på sine egne barn, og fikk heller ikke lov til det.

Historien kunne like godt vært fortalt av en norsk kvinne med en ustabil personlighetsforstyrrelse som lever i en storfamilie uten særlige grenser. Fortellingen om Nuka illustrerer hvor mye rusmisbrukere over hele verden har til felles, og hvor vanskelig det kan være å bli «nykter» på kort tid.

Forfatteren har et slags lege-pasient-forhold til Nuka. Da han møtte henne, og hun gråt, fikk han lyst til å prøve å hjelpe henne. Han gjør det delvis på utradisjonelt vis. Han klemmer henne, lager pizza til henne, oppsøker henne hjemme om kvelden og så videre. Situasjonen hennes endrer seg likevel ikke. Men hun gir ham lov til å skrive hennes fortelling. Slik den er fortalt, innebærer den lite nytt om hasjmisbruk, personlighetsforstyrrelse og Grønland.

\section{Per Vaglum}

Professor emeritus, Avdeling for medisinsk atferdsvitenskap Institutt for medisinske basalfag

Universitetet i Oslo 